Original article

\title{
Vitamin D: Correlation with biochemical and body composition changes in a southern Brazilian population and induction of cytotoxicity in mesenchymal stem cells derived from human adipose
} \section{tissue}

\author{
João Renato Pesarini ${ }^{\mathrm{a}, \mathrm{b}, \mathrm{c}}$, Rodrigo Juliano Oliveira ${ }^{\mathrm{b}, \mathrm{c}, \mathrm{d}, *}$, Lucas Roberto Pessatto $^{\mathrm{c}, \mathrm{d}, \mathrm{e}}$, \\ Andréia Conceição Milan Brochado Antoniolli-Silva ${ }^{\mathrm{b}, \mathrm{c}}$, Ingrid Felicidade ${ }^{\mathrm{f}}$, \\ Nance Beyer Nardi ${ }^{g}$, Melissa Camassola ${ }^{\mathrm{g}}$, Mário Sérgio Mantovani ${ }^{\mathrm{d}}$, \\ Lúcia Regina Ribeiro ${ }^{\mathrm{a}, \mathrm{f}}$
}

\footnotetext{
a São Paulo State University (UNESP), Graduate Programme in Cellular and Molecular Biology, Institute of Biosciences of Rio Claro (IBRC), Rio Claro, São Paulo, Brazil

${ }^{\mathbf{b}}$ Federal University of Mato Grosso do Sul (UFMS), Graduate Programme in Health and Development in the Central-West Region, School of Medicine ( FAMED), Campo Grande, Mato Grosso do Sul, Brazil

c Stem Cell, Cell Therapy and Toxicological Genetics Research Centre (CeTroGen), "Maria Aparecida Pedrossian” University Hospital, Brazilian Hospital Services

Company (EBSERH), Campo Grande, Mato Grosso do Sul, Brazil

d State University of Londrina (UEL), Graduate Programme in Genetics and Molecular Biology, Department of General Biology, Londrina, Paraná, Brazil

${ }^{\mathbf{e}}$ Federal University of Mato Grosso do Sul (UFMS), MSc Programme in Pharmacy, Centre for Biological and Health Sciences (CCBS), Campo Grande, Mato

Grosso do Sul, Brazil

${ }^{\mathrm{f}}$ São Paulo State University (UNESP), Graduate Programme in Pathology, School of Medicine of Botucatu, Botucatu, São Paulo, Brazil

${ }^{\mathrm{g}}$ Lutheran University of Brazil (ULBRA), Graduate Programme in Cellular and Molecular Biology Applied to Health, Canoas, Rio Grande do Sul, Brazil
}

\section{A R T I C L E IN F O}

\section{Article history:}

Received 16 March 2017

Received in revised form 28 April 2017

Accepted 2 May 2017

\section{Keywords:}

Vitamin D deficiency

Calcitriol

Obesity

Stem cells

Population characteristics

\section{A B S T R A C T}

Studies have shown that metabolic disorders, serum inflammatory markers and weight gain (obesity) are correlated with vitamin D deficiency. Therefore, the present study correlated the serum calcidiol (s25 $(\mathrm{OH}) \mathrm{D}_{3}$ ) levels in a sample of individuals from southern Brazil with variables related to metabolic disorders, obesity and lifestyle habits and assessed the cytotoxic effect of calcitriol on adipose tissuederived mesenchymal stem cells (ADSCs). The results showed a 79.23\% prevalence of hypovitaminosis D in the study population and a correlation $(p<0.05)$ between a low serum vitamin D concentration and an elevated low-density lipoprotein cholesterol (LDL-c) level. Univariate linear regression analysis using 25 $(\mathrm{OH}) \mathrm{D}_{3}$ as a regressor showed a negative association $(p<0.05)$ with an indoor work environment ( $\beta=-2.305)$, increased body fat $(\beta=-0.095)$, age $(\beta=-0.065)$ and high-density lipoprotein cholesterol (HDL-c; $\beta=-0.109)$. An in vitro 3-(4,5-dimethylthiazol-2-yl)-2,5-diphenyltetrazolium bromide (MTT) assay performed with ADSCs using five calcitriol concentrations (15.625, 31.25, 62.5, 125 and $250 \mathrm{nM}$ ) indicated cytotoxic potential $(p<0.05)$ at the $62.5 \mathrm{nM}$ concentration at 48 and $72 \mathrm{~h}$ and at the 125 and $250 \mathrm{nM}$ concentrations at 24, 48 and $72 \mathrm{~h}$. The results reported herein corroborate one another and suggest a key association between vitamin D deficiency and the development of obesity because ADSCs are involved in adipose tissue hyperplasia and differentiate into adipocytes that can sequester the bioavailable vitamin D necessary for homeostasis.

(c) 2017 Elsevier Masson SAS. All rights reserved.

\footnotetext{
* Corresponding author at: Medicine College, Federal University of Mato Grosso do Sul. Cidade Universitária, S/N Campo Grande, MS, 79070-900, Brazil.

E-mail address: rodrigo.oliveira@ufms.br (R.J. Oliveira).
}

\section{Introduction}

Vitamin D has become a research study focus primarily because it modulates functions related to bone health [1,2], tumour development [3-5] and metabolic disorders [6-9]. 
One of the various forms of vitamin $D$ is vitamin $D_{3}$ (cholecalciferol), which can be produced through sun exposure (endogenous production) and ingested/supplemented. Therefore, vitamin $\mathrm{D}_{3}$ may be the most studied vitamin in medicine because it is widely used as a supplement in hypovitaminosis D cases. Through a regulated process in the body, circulating vitamin $\mathrm{D}_{3}$ is converted to the bioactive vitamin $\mathrm{D}$ hormone, which is best known as calcitriol $\left(1,25(\mathrm{OH})_{2} \mathrm{D}_{3}\right)$. For this purpose, vitamin $\mathrm{D}_{3}$ undergoes a hydroxylation process that primarily occurs in the liver; this process is mediated by the 25-hydroxylase enzyme, which causes the conversion to calcidiol $\left(25(\mathrm{OH}) \mathrm{D}_{3}\right)$. Subsequently, the second hydroxylation mostly occurs in the kidneys and is, in turn, mediated by the $1 \alpha$-hydroxylase enzyme, which converts 25 $(\mathrm{OH}) \mathrm{D}_{3}$ into $1,25(\mathrm{OH})_{2} \mathrm{D}_{3}[10-13]$. However, optimal serum levels are not reached, even with the ingestion of vitamin $D_{3}$-rich foods [14]; thus, supplementation and sun exposure are needed, preferentially during the morning period [15-17].

Vitamin D deficiency, as assessed using the serum $25(\mathrm{OH}) \mathrm{D}_{3}$ level, has been reported in children, adults and elderly people from all continents [18-20]. Because deficiency occurs worldwide [21,22], further population studies are needed even in countries thought to have a high annual solar incidence [23-26]. In Brazil, vitamin D deficiency is most worrying because this condition affects different groups of study subjects, including young healthy individuals and young people with metabolic disorders (e.g., patients with metabolic syndrome) [27-30].

Systematic reviews have shown that metabolic disorders, including cardiovascular disease (with an increasing incidence), high serum lipid concentrations, serum inflammatory markers, changes in glucose metabolism and weight gain, are correlated with vitamin $\mathrm{D}$ deficiency [9,31-33]. These parameters are related to obesity progression and being overweight in humans. Adipose tissue expansion is mediated by hypertrophy of mature adipocytes or multipotent stem cell hyperplasia during adipogenic differentiation with a subsequent triglyceride accumulation in adipose tissue $[34,35]$. Recently, stem cells adjacent to adipose tissue have been shown to play key roles in the adipose tissue mechanisms underlying chronic inflammation; therefore, these cells may be a key factor in an adjunct treatment for obesity prevention [36]. Thus, studies on the genetic cascade of the inhibition of the proliferation and/or death of adipose tissue cells have provided new possibilities for the prevention of this disease [37-40].

Vitamin D has been reported to be a mesenchymal stem cell proliferation inhibitor and an inducer of apoptosis in various cell types, including adipocytes [37,38,41-43]. Therefore, the use of vitamin $\mathrm{D}$, especially in its hormone form, may be a good strategy to prevent obesity.

Considering the above findings, the present study correlated the serum calcidiol ( $\mathrm{s} 25(\mathrm{OH}) \mathrm{D}_{3}$ ) levels in a sample of individuals from southern Brazil with variables related to metabolic disorders, obesity and lifestyle habits and assessed the cytotoxic effect of 1,25 $(\mathrm{OH})_{2} \mathrm{D}_{3}$, which is commonly found in one type of medication, on adipose tissue-derived mesenchymal stem cells (ADSCs).

\section{Patients and methods}

\subsection{Population study}

\subsubsection{Inclusion criteria}

Adult volunteers of both genders aged from 18 to 55 years who read and signed the informed consent form and lived for at least three months in the city of Londrina, Paraná state, Brazil (Latitude: $23^{\circ} 18^{\prime} 37^{\prime \prime}$ South), were included in the research study. Only selfdeclared Caucasian individuals participated in the research study to follow the standards of similar studies $[44,45]$ and to avoid effects from skin vitamin $\mathrm{D}$ production due to excess pigmentation.
The study was submitted to the Ethics Committee on Research Involving Human Subjects of the State University of Londrina (Universidade Estadual de Londrina-UEL) and approved under opinion number 116/2011.

\subsubsection{Exclusion criteria}

Patients with cardiovascular, gastrointestinal or kidney diseases, thyroid disorders, diabetes, haemophilia, anaemia or cancer, individuals who did not reside in the municipality of Londrina for at least three months and those who were not self-reported Caucasians were excluded from the study. Individuals who reported the chronic use of medicines to treat diabetes mellitus or dyslipidaemia or who used multivitamins in the last six months were also excluded from the study.

\subsubsection{Data on the initial and final sampling}

The present study was announced in the Oswaldo Cruz Laboratory (Londrina - PR) to patients waiting for the collection of their routine exams. At that time, the researcher responsible for this work invited patients to include the evaluated exams at no additional cost and explained the importance of their contribution. A total of 370 patients demonstrated an interest in participating and authorised blood collection for vitamin $\mathrm{D}$ and other biochemical variable dosing.

\subsubsection{General data and sample collection procedures}

Biological material and data on anthropometric parameters were collected over a six-month period. The collections were performed two weeks after the beginning of spring and two weeks after the end of summer in 2013.

The experiment was performed with a double-blind design. The following materials were provided to each volunteer: a standard care questionnaire, wherein personal information (name, age, gender, address, ethnicity and use of medicines) was recorded, and the shortened and modified version of the International Physical Activity Questionnaire (IPAQ; [46]). The data recorded on the latter questionnaire were based on the objectives of the study and included daily sun exposure determined by workplace specifications, sunscreen use habits and whether vigorous/moderate physical activity was performed. Additionally, the volunteer was subjected to a rapid blood glucose test (Accu-Check Active ${ }^{\circledR}$, Roche Diagnostics, Switzerland). If the result indicated values higher than $126 \mathrm{mg} / \mathrm{dL}$, the subject was automatically excluded from the study and referred for medical evaluation. After this initial evaluation, the subjects were referred for biological material collection and anthropometric evaluation. The aforementioned procedures were performed in the morning from 08:00 to 10:00 AM to minimise externalities that could cause variations between the tested parameters.

\subsubsection{Determination of biochemical variables}

The $s 25(\mathrm{OH}) \mathrm{D}_{3}$ values were evaluated using an automated chemiluminescence analyser (LIAISON ${ }^{\circledR}$, DiaSorin Diagnostics, Italy). Free fatty acids, high-density lipoprotein cholesterol (HDL-c), triglycerides and glucose were assessed using the automated enzymatic-calorimetric method (ADVIA ${ }^{\circledR}$ 1650, Siemens, Germany). Low-density lipoprotein cholesterol (LDL-c) was calculated using the Friedewald equation [47].

\subsubsection{Anthropometric evaluation}

For the anthropometric examination, the waist circumference was measured using an inelastic tape measure (Incoterm ${ }^{\circledR}$, Brazil). Bioelectric impedance analysis was performed using a MALTRON ${ }^{\circledR}$ BF-906 Body Composition Analyser (Maltron International, UK) to assess the percentage of body fat and the body mass index (BMI). 


\subsection{In vitro study}

\subsubsection{Individuals}

Individuals living in Campo Grande, Mato Grosso do Sul state, Brazil (latitude: $20^{\circ} 26^{\prime} 34^{\prime \prime}$ South), who were referred for liposuction and scheduled for surgery were contacted and informed about the research study. Three adult female volunteers aged from 20 to 40 years who read and signed the informed consent form were selected. The study was submitted to the Ethics Committee on Research Involving Human Subjects of the Federal University of Mato Grosso do Sul (Universidade Federal de Mato Grosso do SulUFMS) and approved under opinion number 867.377.

\subsubsection{Procedures for liposuction, lipoaspirate processing and mesenchymal stem cell culture}

After the anaesthetic procedure, asepsis and antisepsis, surgical incisions of approximately $1.0 \mathrm{~cm}$ were made into the anterolateral abdominal wall to collect the biological material. Approximately $200 \mathrm{~mL}$ of saline solution without a vasoconstrictor was injected into the adipose stroma for tissue detachment. Then, the detached adipose tissue was collected using a liposuction cannula. This $0.5-$ $\mathrm{cm}$ medium-calibre cannula was coupled to a $50-\mathrm{mL}$ syringe for fat collection. Approximately $300 \mathrm{~mL}$ of biological material was collected in a sterile container with $200 \mathrm{~mL}$ of phosphate-buffered solution (PBS; $8 \mathrm{~g} \mathrm{NaCl}, 0.2 \mathrm{~g} \mathrm{KCl}, 1.15 \mathrm{~g} \mathrm{Na}_{2} \mathrm{HPO}_{4}, 0.2 \mathrm{~g} \mathrm{KH}_{2} \mathrm{PO}_{4}$ and $1000 \mathrm{~mL}$ of deionised water). Shortly thereafter, the liposuction surgical procedure was performed according to the most appropriate technique for the patient. The crude lipoaspirate of each patient was only stored to collect the data for the present study and was later discarded in a biohazard waste container, followed by hospital waste disposal. For the processing of each of the three lipoaspirate samples, collagenase was used for sample digestion as described by Markarian, Frey, Silveira, Chem, Milani, Ely, Horn, Nardi and Camassola [48] with modifications. Culture medium was composed of Dulbecco's modified Eagle's medium with $10 \mathrm{mM}$ HEPES (HDMEM; Sigma ${ }^{\circledR}$ catalogue number D5523) supplemented with $10 \%$ foetal bovine serum.

The immunophenotype was characterised by flow cytometry. Cells were incubated with antibodies against phycoerythrin or fluorescein isothiocyanate-conjugated antibodies specific for human CD44, CD90, CD29, CD34, CD11b and major histocompatibility complex (MHC) II (PharMingen BD, USA) for $30 \mathrm{~min}$ at $4{ }^{\circ} \mathrm{C}$. Control samples were incubated in the absence of antibodies. The cells were analysed on an ACCURI C6 (Becton Dickinson, USA). The characterisation graphs were generated with the capture of 10,000 events using the standard software for the equipment (BD ACCURI C6 software; Becton Dickinson, USA).

\subsubsection{Adipogenic differentiation}

Cell samples from the three patients were subjected to the adipogenic differentiation process at the fifth passage. To induce differentiation, $1.0 \times 10^{5}$ cells were seeded into 6-well culture plates; after cell adhesion $(24 \mathrm{~h})$, the cells were cultured in adipogenesis-inducing medium according to Markarian, Frey, Silveira, Chem, Milani, Ely, Horn, Nardi and Camassola [48] with modifications. In summary, $0.714 \mu \mathrm{L}$ of insulin (Insunorm $\mathrm{R}^{\mathbb{R}}$, Aspen Pharma/Aspen Brazil, $0.35 \mathrm{mg} / \mathrm{mL}$ ), $100 \mu \mathrm{M}$ indomethacin $\left(0.0447 \mathrm{~g}\right.$ indomethacin, Sigma ${ }^{\circledR}$ catalogue number $\mathrm{I7378}$, in $5 \mathrm{~mL}$ of dimethyl sulfoxide (DMSO)), $3.5 \mu \mathrm{M}$ rosiglitazone $(0.0089 \mathrm{~g}$ of rosiglitazone, Sigma ${ }^{\circledR}$ catalogue number R2408, in $5 \mathrm{~mL}$ of DMSO) and $10^{-5} \mathrm{M}$ dexamethasone (Sigma ${ }^{\circledR}$ catalogue number D4902) were used for every $1 \mathrm{~mL}$ of HDMEM supplemented with $20 \%$ foetal bovine serum. All solutions were stored in a freezer except for indomethacin, which was stored at room temperature. The differentiation medium was prepared on the day of use.
The differentiation medium was changed every $72 \mathrm{~h}[49,50]$, and the differentiation process lasted 14 days [51,52].

After the differentiation medium was discarded, the cells were fixed for $60 \mathrm{~min}$ at room temperature with $10 \%$ formaldehyde. Then, the cells were washed with isopropanol (60\%) and subsequently incubated with Oil red O (Sigma ${ }^{\circledR}$ catalogue number O0625) for $20 \mathrm{~min}$ at room temperature to detect intracellular lipid accumulation. The excess dye was removed by washing with distilled water.

\subsubsection{Osteogenic differentiation}

The cells were cultured as described above for the adipogenic induction. However, the cells were grown in their own medium for osteogenic differentiation, as described by Markarian, Frey, Silveira, Chem, Milani, Ely, Horn, Nardi and Camassola [48], with modifications.

In total, $79.9 \mathrm{~mL}$ of HDMEM supplemented with $10 \%$ foetal bovine serum, $100 \mu \mathrm{L}$ of ascorbic acid solution ( $50 \mathrm{mg}$ of ascorbic acid 2-phosphate, Sigma ${ }^{\circledR}$ catalogue number A8960, in $10 \mathrm{~mL}$ of HDMEM), $100 \mathrm{~mL}$ of $\beta$-glycerophosphate stock solution (630 mg of $\beta$-glycerophosphate, Sigma ${ }^{\mathbb{R}}$ catalogue number G9891, in $20 \mathrm{~mL}$ of HDMEM) and $10 \mathrm{~mL}$ of foetal bovine serum was used to prepare the osteogenic induction medium.

The differentiation medium was changed every $72 \mathrm{~h}$ for four weeks. Osteogenic differentiation was demonstrated by the observation of calcium deposits stained with Alizarin Red (Sigma ${ }^{\circledR}$ catalogue number A5533) as described by Markarian, Frey, Silveira, Chem, Milani, Ely, Horn, Nardi and Camassola [48].

\subsubsection{Chondrogenic differentiation}

The cells were cultured as described for the adipogenic and osteogenic induction methods. After cell adhesion, the HDMEM supplemented with $10 \%$ foetal bovine serum was discarded, and the cells were cultured using a STEMPRO chondrogenic differentiation kit (Gibco ${ }^{\circledR}$ Life Technologies, catalogue number A1007101) according to the manufacturer's instructions for 21 days. The culture medium was changed every three days.

After the differentiation medium was discarded, the cells were fixed for $30 \mathrm{~min}$ at room temperature with a paraformaldehyde solution (4\%). Then, the cells were washed twice with PBS and stained with Alcian Blue (Neon Commercial ${ }^{\circledR}$, Brazil, catalogue number 74240) for $5 \mathrm{~min}$ at room temperature; excess dye was removed by washing with distilled water [53]. Differentiation was confirmed by the presence of a glycosaminoglycan-rich extracellular matrix on the 21st day.

\subsubsection{Test substance: $1,25(\mathrm{OH})_{2} D_{3}$}

The commercial product Calcijex ${ }^{\circledR}$ (Abbott Pharmaceuticals, USA; $\left.1,25(\mathrm{OH})_{2} \mathrm{D}_{3}, 1 \mu \mathrm{g} / \mathrm{mL}\right)$ was used to assess cell viability (cytotoxic potential). This drug was chosen because it could be easily purchased from several locations worldwide, which facilitated its use in treatments.

\subsubsection{MTT assay}

The 3-(4,5-dimethylthiazol-2-yl)-2,5-diphenyltetrazolium bromide (MTT) assay was performed as described by Mosmann [54] with modifications [55]. Cells from the three patients were seeded $\left(7 \times 10^{3}\right.$ cells/well, five wells per treatment) in 96-well culture plates. After a 24 -h stabilisation period, the cells were separated into six groups as follows: a control group incubated with HDMEM (supplemented with $10 \%$ foetal bovine serum) alone and five treatment groups incubated with five $1,25(\mathrm{OH})_{2} \mathrm{D}_{3}$ concentrations $(15.625,31.25,62.5,125$ and $250 \mathrm{nM})$ for 24,48 and $72 \mathrm{~h}$. At the end of the treatment periods, the treatment media were removed, and the cells were incubated at $37^{\circ} \mathrm{C}$ with a mixture containing MTT (Invitrogen ${ }^{\circledR}$ catalogue number M6494; $0.005 \mathrm{~g}$ of MTT, $5 \mathrm{~mL}$ of 
PBS and $10 \mathrm{~mL}$ of HDMEM without FBS supplementation) for $4 \mathrm{~h}$. Then, the MTT mixture was removed and replaced with $200 \mu \mathrm{L}$ of dimethyl sulfoxide (DMSO) in each well to dissolve the product (formazan crystals). Readings were performed in a spectrophotometer with a 570-nm filter. Cell viability (expressed as a percentage) was calculated according to the following formula:

$$
\text { Cell Viability }(\%)=
$$

Mean Absorbance of the treatment group Mean Absorbance of the group without treatment $\times 100$

\subsection{Statistical analysis}

The subjects of the population study were classified according to their $\mathrm{s} 25(\mathrm{OH}) \mathrm{D}_{3}$ levels as vitamin D-sufficient $(\geq 30 \mathrm{ng} / \mathrm{mL})$ or vitamin D-insufficient/deficient $(<30 \mathrm{ng} / \mathrm{mL})$ subjects [24,56]. Descriptive analysis data were expressed as the mean \pm standard error of the mean (SEM) or $\mathrm{n} / \%$, and both groups were compared using the Mann-Whitney test. Each group was separately fitted to the univariate linear regression model to examine the potential of each regressor and the behaviour of both groups when $s 25(\mathrm{OH}) \mathrm{D}_{3}$ was used as the dependent variable. Then, the full multiple regression model was analysed by variable using a stepwise procedure. For each group, only the variables that actually contributed to a good model fit were included to provide a reduced model. Scatter plots were generated, and Pearson's correlation coefficients were calculated for $s 25(\mathrm{OH}) \mathrm{D}_{3}$ and the clinical-laboratory and categorical variables selected after the stepwise procedure. The significance level adopted for all tests was 0.05. All tests were performed in R software 2.15.0 ( $R, 2011$ ).

The MTT assay results were expressed as the percentage \pm SEM. The statistical analysis was performed using analysis of variance (ANOVA)/Bonferroni's correction, with different letters indicating significant differences ( $p<0.05$; GraphPad Prism 5). A non-linear regression curve analysis was performed using the results from the test with the five $1,25(\mathrm{OH})_{2} \mathrm{D}_{3}$ concentrations (OriginPro ${ }^{\circledR} 2016$ ) to determine the half-maximal inhibitory concentration (IC50) of $1,25(\mathrm{OH})_{2} \mathrm{D}_{3}$.

\section{Results}

\subsection{Population study}

The subjects were categorised according to their s25(OH)D levels. A total of $79.23 \%$ of the sample consisted of vitamin Ddeficient subjects $\left(\mathrm{s} 25(\mathrm{OH}) \mathrm{D}_{3}<30 \mathrm{ng} / \mathrm{mL}\right)$, and $20.77 \%$ of the sample consisted of vitamin D-sufficient subjects $\left(\mathrm{s} 25(\mathrm{OH}) \mathrm{D}_{3} \geq 30\right.$ $\mathrm{ng} / \mathrm{mL}$; Table 1$)$. The mean vitamin $\mathrm{D}$ concentration was $21.06 \pm 0.34 \mathrm{ng} / \mathrm{mL}$ for subjects with a $\mathrm{s} 25(\mathrm{OH}) \mathrm{D}_{3}$ concentration $<30 \mathrm{ng} / \mathrm{mL}$ and $35.77 \pm 0.63 \mathrm{ng} / \mathrm{mL}$ for subjects with a s25(OH)D $\mathrm{D}_{3}$ concentration $\geq 30 \mathrm{ng} / \mathrm{mL}$. These serum concentrations were significantly different $(p<0.001)$ and were similar to the plasma LDL-c levels, which were $113.48 \pm 1.96 \mathrm{mg} / \mathrm{dL}$ in the $\mathrm{s} 25(\mathrm{OH})$ $\mathrm{D}_{3}<30 \mathrm{ng} / \mathrm{mL}$ group and $98.41 \pm 3.48 \mathrm{mg} / \mathrm{dL}$ in the $\mathrm{s} 25(\mathrm{OH})$ $\mathrm{D}_{3} \geq 30 \mathrm{ng} / \mathrm{mL}$ group $(p<0.001)$. A high coefficient of variation was observed for these and all other tested variables, indicating sample heterogeneity (Table 1 ).

A univariate regression analysis was performed for all variables tested according to the categorisation model. Table 2 outlines the parameter estimates, the confidence intervals of these estimates and the $p$-value of Student's $t$-test for the slope of the linear regression model for the $\mathrm{s} 25(\mathrm{OH}) \mathrm{D}_{3}<30 \mathrm{ng} / \mathrm{mL}$ subjects. For this group, the following variables were significant: sun exposure (indoor work environment) $(p=0.001)$, age $(p=0.032)$, body fat percentage $(p=0.013)$ and HDL-c plasma level $(p<0.001)$. Similarly, a univariate linear regression analysis was performed for the $\mathrm{s} 25(\mathrm{OH}) \mathrm{D}_{3} \geq 30 \mathrm{ng} / \mathrm{mL}$ subjects (Table 3 ). However, no variables were significant in this regression model.

Subsequently, the variables best fitted to each categorisation model were selected. For this purpose, variables were selected from the full model using a stepwise procedure to choose the variables that best predicted each model. After the selection, a multivariate regression analysis was performed for both groups. The variables $(p<0.05)$ age, BMI, HDL-c and sun exposure (indoor work environment) were selected for the s25(OH)D $3<30 \mathrm{ng} / \mathrm{mL}$ model (Table 4). However, no variable had significant predictability $(p<0.05)$ for the $\mathrm{s} 25(\mathrm{OH}) \mathrm{D}_{3} \geq 30 \mathrm{ng} / \mathrm{mL}$ model (data not shown).

Table 1

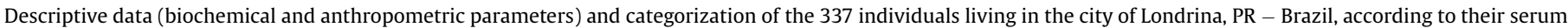
calcidiol $\left(25(\mathrm{OH}) \mathrm{D}_{3}\right)$ levels.

\begin{tabular}{|c|c|c|c|c|c|c|c|c|c|c|c|}
\hline & \multicolumn{5}{|c|}{$\mathrm{s} 25(\mathrm{OH}) \mathrm{D} 3<30 \mathrm{ng} / \mathrm{mL}$} & \multicolumn{5}{|c|}{$\mathrm{s} 25(\mathrm{OH}) \mathrm{D} 3 \geq 30 \mathrm{ng} / \mathrm{mL}$} & \multirow{3}{*}{$p^{a}$} \\
\hline & \multicolumn{5}{|c|}{$\mathrm{n}=267$} & \multicolumn{5}{|c|}{$\mathrm{n}=70$} & \\
\hline & & & Range & $95 \% \mathrm{CI}$ & $\mathrm{CV}(\%)$ & & & Range & $95 \% \mathrm{CI}$ & CV $(\%)$ & \\
\hline Gender (female, n/\%) & 189 & 70.80 & & & & 52 & 74.30 & & & & 0.565 \\
\hline Physical activity (not performed, n/\%) & 234 & 87.60 & & & & 63 & 90.00 & & & & 0.588 \\
\hline Sun exposure (indoor work environment, $\mathrm{n} / \%$ ) & 169 & 63.30 & & & & 38 & 54.30 & & & & 0.169 \\
\hline Sunscreen use (yes, n/\%) & 78 & 29.21 & & & & 23 & 32.86 & & & & 0.555 \\
\hline Age (years, mean/SE) & 33.34 & 0.69 & $17.00-55.00$ & $31.98-34.70$ & 33.80 & 32.37 & 1.13 & $19.00-55.00$ & $30.12-34.62$ & 29.13 & 0.929 \\
\hline Waist circumference $(\mathrm{cm}$, mean/SE) & 83.94 & 0.75 & $61.00-116.00$ & $82.46-85.41$ & 14.59 & 82.17 & 1.44 & $63.00-115.00$ & $79.30-85.04$ & 14.64 & 0.275 \\
\hline Body fat $(\%$, mean $/ \mathrm{SE})$ & 31.59 & 0.55 & $12.00-54.20$ & $30.52-32.67$ & 28.27 & 30.55 & 0.98 & $14.00-48.40$ & $28.60-32.49$ & 26.74 & 0.379 \\
\hline BMI $\left(\mathrm{kg} / \mathrm{m}^{2}\right.$, mean $\left./ \mathrm{SE}\right)$ & 25.33 & 0.28 & $17.10-41.00$ & $24.77-25.88$ & 18.16 & 24.82 & 0.52 & $17.40-37.00$ & $23.79-25.85$ & 17.49 & 0.442 \\
\hline HDL-c (mg/dL, mean/SE) & 54.63 & 0.72 & $30.00-97.00$ & $53.22-56.05$ & 21.47 & 54.4 & 1.34 & $36.00-89.00$ & $51.74-57.06$ & 20.53 & 0.903 \\
\hline LDL-c (mg/dL, mean/SE) & 113.48 & 1.96 & $39.60-220.80$ & $\begin{array}{l}109.62- \\
117.35\end{array}$ & 28.28 & 98.41 & 3.48 & $36.60-167.20$ & $91.47-105.35$ & 29.59 & $<0.001$ \\
\hline Triglycerides (mg/dL, mean/SE) & 102.72 & 3.96 & $\begin{array}{l}28.00- \\
445.00\end{array}$ & $94.91-110.52$ & 63.05 & 98.73 & 8.99 & $\begin{array}{l}26.00- \\
449.00\end{array}$ & $\begin{array}{l}80.79- \\
116.67\end{array}$ & 76.20 & 0.326 \\
\hline Free fatty acids (nmol/mL, mean/SE) & 0.55 & 0.01 & $0.21-1.28$ & $0.53-0.57$ & 32.73 & 0.56 & 0.03 & $0.25-1.33$ & $0.51-0.61$ & 37.50 & 0.692 \\
\hline Glucose (mg/dL, median/SE) & 90.09 & 0.50 & $57.00-115.00$ & $89.10-91.07$ & 9.09 & 88.51 & 1.06 & $60.00-109.00$ & $86.39-90.64$ & 10.07 & 0.240 \\
\hline $25(\mathrm{OH}) \mathrm{D}_{3}$ (calcidiol; ng/mL, mean/SE) & 21.06 & 0.34 & $4.09-29.90$ & $20.39-21.73$ & 26.54 & 35.77 & 0.63 & $30.00-52.70$ & $34.52-37.03$ & 14.73 & $<0.001$ \\
\hline
\end{tabular}

Comparative table of biochemical and anthropometric parameters categorized by the serum calcidiol levels.

a Statistical analysis: Mann-Whitney $(\mathrm{p}<0.05) .95 \%$ confidence interval $(95 \% \mathrm{CI})$. 
Table 2

Univariate linear regression model for the subjects with an $\mathrm{s} 25(\mathrm{OH}) \mathrm{D}_{3}$ concentration $<\mid 30 \mathrm{ng} / \mathrm{mL}$ (subjects with calcidiol serum levels below $30 \mathrm{ng} / \mathrm{mL}$ ).

\begin{tabular}{|c|c|c|c|c|}
\hline & $\beta$ Coefficient & $95 \% \mathrm{CI}$ & & $p^{\mathrm{a}}$ \\
\hline Physical activity (not performed) & -1.728 & -3.768 & 0.312 & 0.097 \\
\hline Sun exposure (indoor work environment) & -2.305 & -3.677 & -0.933 & $0.001^{*}$ \\
\hline Sunscreen use (yes) & 0.439 & -1.044 & 1.923 & 0.560 \\
\hline Age (years) & -0.065 & -0.125 & -0.006 & $0.032^{*}$ \\
\hline Waist circumference $(\mathrm{cm})$ & -0.008 & -0.063 & 0.048 & 0.782 \\
\hline Body fat $(\%)$ & -0.095 & -0.170 & -0.020 & $0.013^{*}$ \\
\hline $\operatorname{BMI}\left(\mathrm{kg} / \mathrm{m}^{2}\right)$ & -0.097 & -0.243 & 0.050 & 0.194 \\
\hline HDL-c (mg/dL) & -0.109 & -0.165 & -0.053 & $<0.001^{*}$ \\
\hline $\mathrm{LDL}-\mathrm{c}(\mathrm{mg} / \mathrm{dL})$ & -0.008 & -0.029 & 0.013 & 0.445 \\
\hline Triglycerides $(\mathrm{mg} / \mathrm{dL})$ & $<-0.001$ & -0.010 & 0.011 & 0.917 \\
\hline Free fatty acids $(\mathrm{nmol} / \mathrm{mL})$ & -1.917 & -5.609 & 1.776 & 0.308 \\
\hline Glucose $(\mathrm{mg} / \mathrm{dL})$ & 0.037 & -0.045 & 0.120 & 0.375 \\
\hline
\end{tabular}

a Statistical test: Student's $t$-test.

* Statistically significant difference $(p<0.05) .95 \%$ confidence interval $(95 \% \mathrm{CI})$.

Table 3

Univariate linear regression model for subjects with an s25(OH) $\mathrm{D}_{3}$ concentration $\geq 30 \mathrm{ng} / \mathrm{mL}$ (subjects with calcidiol serum levels above $30 \mathrm{ng} / \mathrm{mL}$ ).

\begin{tabular}{|c|c|c|c|c|}
\hline & $\beta$ Coefficient & $95 \% \mathrm{CI}$ & & $p^{\mathrm{a}}$ \\
\hline Physical activity (not performed) & 1.048 & -3.165 & 5.260 & 0.621 \\
\hline Sun exposure (indoor work environment) & 0.943 & -1.588 & 3.475 & 0.460 \\
\hline Sunscreen use (yes) & -0.145 & -2.841 & 2.550 & 0.915 \\
\hline Age (years) & -0.067 & -0.125 & -0.006 & 0.325 \\
\hline Waist circumference $(\mathrm{cm})$ & -0.010 & -0.116 & 0.096 & 0.857 \\
\hline Body fat $(\%)$ & 0.083 & -0.072 & 0.237 & 0.291 \\
\hline $\operatorname{BMI}\left(\mathrm{kg} / \mathrm{m}^{2}\right)$ & -0.030 & -0.324 & 0.264 & 0.842 \\
\hline HDL-c (mg/dL) & 0.008 & -0.106 & 0.122 & 0.886 \\
\hline $\mathrm{LDL}-\mathrm{c}(\mathrm{mg} / \mathrm{dL})$ & -0.017 & -0.060 & 0.027 & 0.446 \\
\hline Triglycerides $(\mathrm{mg} / \mathrm{dL})$ & -0.006 & -0.023 & 0.011 & 0.468 \\
\hline Free fatty acids $(\mathrm{nmol} / \mathrm{mL})$ & -1.284 & -7.374 & 4.807 & 0.675 \\
\hline Glucose $(\mathrm{mg} / \mathrm{dL})$ & 0.043 & -0.100 & 0.186 & 0.552 \\
\hline
\end{tabular}

a Statistical test: Student's $t$-test $(p<0.05)$. 95\% confidence interval $(95 \% \mathrm{CI})$.

Table 4

Multivariate linear regression model for subjects with an s25(OH) $\mathrm{D}_{3}$ concentration $<30 \mathrm{ng} / \mathrm{mL}$ (subjects with calcidiol serum levels below $30 \mathrm{ng} / \mathrm{mL}$ ).

\begin{tabular}{|c|c|c|c|c|}
\hline & $\beta$ Coefficient & $95 \% \mathrm{CI}$ & & $p$ \\
\hline \multicolumn{5}{|l|}{$\mathrm{s} 25(\mathrm{OH}) \mathrm{D}_{3}<30 \mathrm{ng} / \mathrm{mL}$ model } \\
\hline Age (years) & -0.076 & -0.141 & -0.010 & $0.02^{*}$ \\
\hline BMI $\left(\mathrm{kg} / \mathrm{m}^{2}\right)$ & -0.213 & -0.376 & -0.050 & $0.01^{*}$ \\
\hline HDL-c $(\mathrm{mg} / \mathrm{dL})$ & -0.104 & -0.159 & -0.049 & $<0.001^{*}$ \\
\hline Glucose $(\mathrm{mg} / \mathrm{dL})$ & 0.108 & 0.015 & 0.202 & $0.02^{*}$ \\
\hline Sun exposure (indoor work environment) & -2.593 & -3.933 & -1.253 & $<0.001^{*}$ \\
\hline
\end{tabular}

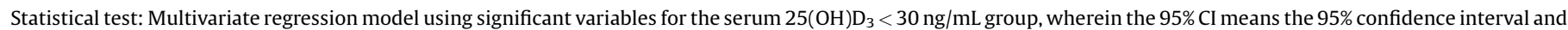
$p$ is the $p$-value of the model variable.

Statistically significant difference $(\mathrm{p}<0.05)$.

Pearson's correlation analysis and an analysis using scatter plots were performed with the variables used in the multivariate regression analysis. The variables age $(r=-0.131, p<0.05)$, BMI $(r=-0.080, p<0.05)$, HDL-c $(r=0,229, \mathrm{p}<0.001)$ and sun exposure (indoor work environment) $(r=-0.199, p=0.05)$ were significant (Fig. 1) for the $\mathrm{s} 25(\mathrm{OH}) \mathrm{D}_{3}<30 \mathrm{ng} / \mathrm{mL}$ model.

\subsection{In vitro study}

\subsubsection{ADSC differentiation}

The culture of undifferentiated cells and the confirmation of adipogenic, osteogenic and chondrogenic differentiation are shown in Fig. 2a-d, respectively. The accumulation of lipids stained with Oil red $\mathrm{O}$ is shown in Fig. $2 \mathrm{~b}$, whereas calcium deposits stained with Alizarin Red are shown in Fig. 2c. Conversely, the glycosaminoglycan-rich extracellular matrix stained with Alcian Blue is shown in Fig. 2d.

\subsubsection{MTT assay}

The MTT assay for cell viability showed the following results for the tested concentrations $(15.625,31.25,62.5,125$ and $250 \mathrm{nM})$ : $93.90 \pm 1.91, \quad 93.92 \pm 2.77, \quad 87.20 \pm 2.22, \quad 52.74 \pm 9.94$ and $24.70 \pm 7.03$ in the 24 -h period; $91.80 \pm 4.52,88.53 \pm 2.98$, $75.09 \pm 5.77,45.10 \pm 11.48,24.46 \pm 7.50$ in the 48 -h period and $87.11 \pm 3.82, \quad 83.79 \pm 2.26, \quad 66.22 \pm 4.87, \quad 34.61 \pm 8.91 \quad$ and $16.83 \pm 3.32$ in the 72 -h period, respectively (Fig. 3a). The statistical analysis showed no significant differences in cell viability between treatment with the $15.625 \mathrm{nM}$ and $31.25 \mathrm{nM}$ $1,25(\mathrm{OH})_{2} \mathrm{D}_{3}$ concentrations and the control $(p>0.05)$ at any treatment time point. The $62.5 \mathrm{nM} 1,25(\mathrm{OH})_{2} \mathrm{D}_{3}$ concentration significantly decreased $(p<0.05)$ the cell viability at 48 and $72 \mathrm{~h}$. Moreover, the 125 and $250 \mathrm{nM} 1,25(\mathrm{OH})_{2} \mathrm{D}_{3}$ concentrations had significant effects $(p<0.05)$ on cell viability at all treatment time points (b). 

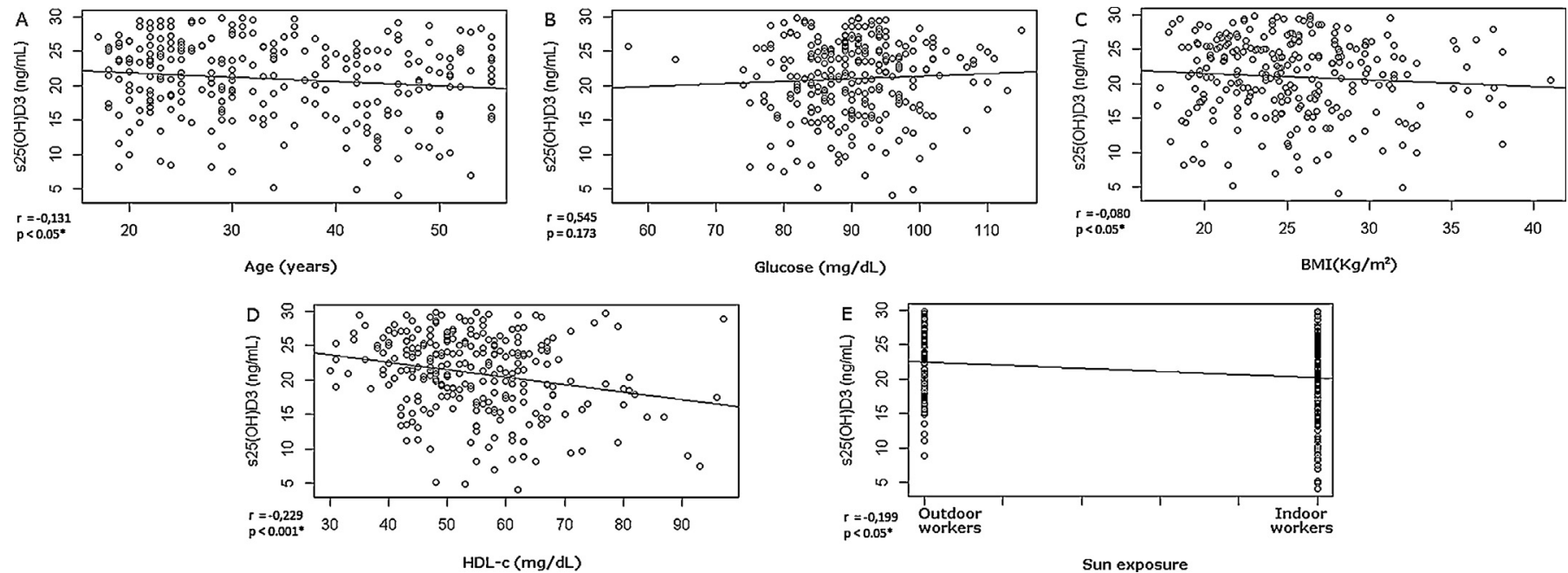

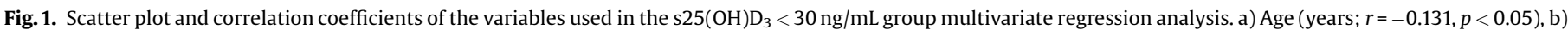

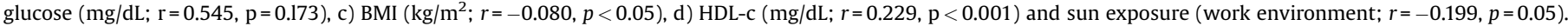

\subsubsection{IC50 calculation}

The calculated IC50 of $1,25(\mathrm{OH})_{2} \mathrm{D}_{3}$ for the 24-h treatment was $138.97 \mathrm{nM}$. A qualitative evaluation was performed for the same concentration and treatment time. The number of cells per field of view decreased, cytoplasmic extensions were observed, the appearance was no longer fibroblastoid, and adhesiveness occurred; these changes caused the cells to adopt a rounded appearance (Fig. 4).

\section{Discussion}

The present study detected hypovitaminosis D in a sample of adult individuals from southern Brazil. The same finding was also reported by other population studies conducted in cities of the southeast, central-west and north regions [24,27,57-59], indicating that this public health problem is not limited to a specific Brazilian demographic region.

In Brazil, the consumption of vitamin D-rich foods is considered low [27] and is characterised as inadequate throughout the country according to the Brazilian Family Budget Survey (Pesquisa Brasileira de Orçamento Familiar) [60]. This inadequate consumption affects several age groups ( 10 to 13,14 to 18,19 to 59 and 60 years and older) and both genders. Furthermore, rare sun exposure and the sedentary lifestyle typical of the study populations [61,62] aggravate the condition, even though Brazil is a tropical country with a high solar incidence for most of the year. Brazilian population studies have shown weight gain and confirmed the prevalence of hypovitaminosis D [24,63].

The two key determinants of s25(OH)D3 are sun exposure and the body fat percentage according to Bolland, Grey, Ames, Mason, Horne, Gamble and Reid [64]. Therefore, sun exposure should ideally occur at least three times a week for 5 to $15 \mathrm{~min}$ from 10 $\mathrm{AM}$ to $3 \mathrm{PM}$. This exposure time would suffice for vitamin D production under ideal conditions [65]. We should emphasise that moderate sunscreen use has no effect on the conversion of 7dehydrocholesterol into vitamin $\mathrm{D}_{3}$ [66]. However, because an increase in sun exposure tends to be insufficient in the presence of a high percentage of body fat, supplementation is required under these circumstances [67]. The negative association between $s 25(\mathrm{OH}) \mathrm{D}_{3}$ and body fat may be attributed to the sequestration of fat-soluble, skin-generated or supplemented vitamin $\mathrm{D}$ in adipocytes before the transport of this molecule to the liver for conversion into $25(\mathrm{OH}) \mathrm{D}_{3}[24]$. Therefore, we can use these facts to explain the results from this research study, which showed hypovitaminosis D in $79.23 \%$ of the sample.

The univariate data analysis showed that only the $25(\mathrm{OH}) \mathrm{D}_{3}$ and LDL-c levels were significantly different between the groups. Vitamin D deficiency affects various metabolic factors of the body, including dyslipidaemia, and thus provides a justification for testing the correlation between vitamin $\mathrm{D}$ and the development of cardiovascular diseases [68-71]. Furthermore, Yin, Sun, Zhang, Lu, Sun, Cui and Wang [72] reported that LDL-c might be the most important of the risk factors that increase the risk for cardiovascular diseases. Thus, this dyslipidaemic factor must be studied to improve the quality of life of the community.

Circulating LDL-c may be oxidised by free radicals, triggering the inflammatory process in blood vessels and thereby recruiting macrophages, which absorb LDL-c particles. Due to their inability to hydrolyse LDL-c, macrophages become foam cells, which are deposited and agglomerate in blood vessel walls and cause atheroma plaques [73]. The main mechanism of LDL-c removal is known as reverse cholesterol transport or cholesterol efflux and occurs when the endogenous cholesterol of peripheral cells and macrophages is removed by binding to HDL-c particles, thereby reducing the atheromatous plaques [74]. The fat-soluble nature of vitamin D leads to a correlation between LDL-c, HDL-c and vitamin $\mathrm{D}$, suggesting that LDL-c removal may be mediated by vitamin $\mathrm{D}$ because macrophages have the vitamin D receptor (VDR) [75]. Thus, vitamin D plays a key role in regulating reverse cholesterol transport [76], modulating genes related to the increase in the cholesterol efflux, including $A B C A 1$ [77] and others [78], and inducing the polarisation of anti-inflammatory macrophages, thereby partially limiting the formation of atheromatous plaques [79-81].

The mean HDL-c concentration of the study population was almost identical to and within the levels recommended by the American Society of Cardiology [82] and was close to the values considered optimal (HDL-c $\geq 60 \mathrm{ng} / \mathrm{mL}$ ). Conversely, the population with $\mathrm{s} 25(\mathrm{OH}) \mathrm{D}_{3}<30 \mathrm{ng} / \mathrm{mL}$ showed a significant negative correlation between vitamin D and HDL-c. This finding indicated that vitamin D failed to modulate the HDL-c levels in the present research study. Although most studies showed opposite results 

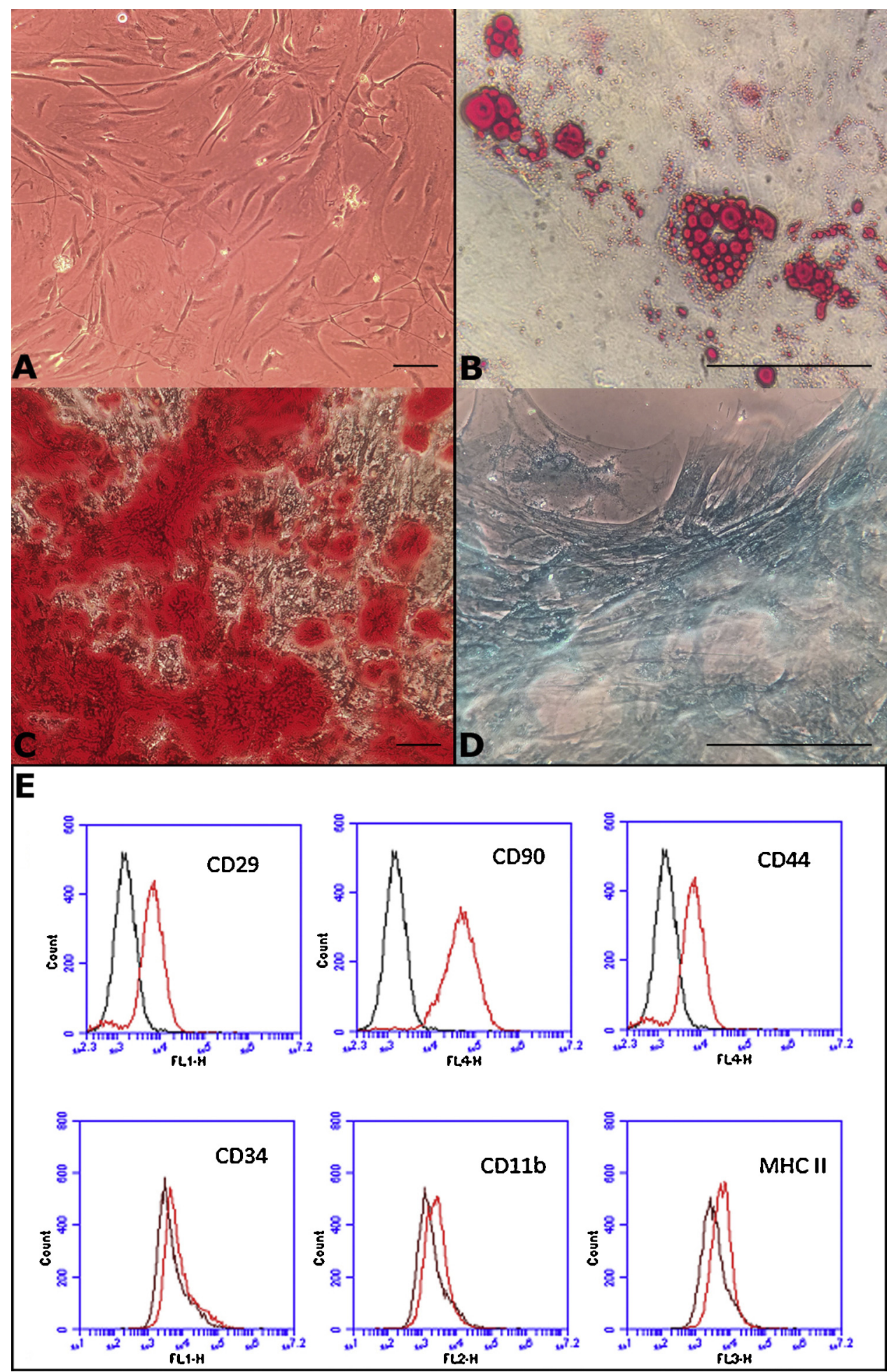

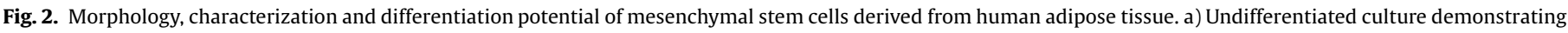

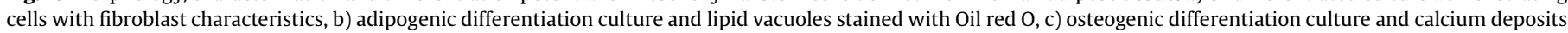

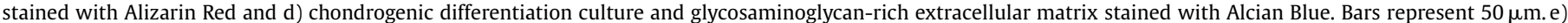

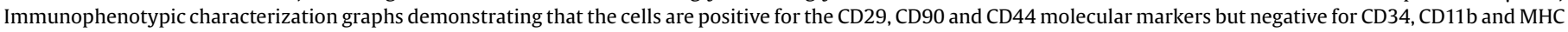
II.

from this finding $[7,83,84]$, some studies, including vitamin D supplementation studies, showed no increase [85] and/or a decrease in the HDL-c profile [86-88]; thus, the vitamin D and HDL interaction has not been completely elucidated. Other variables of our study, including triglycerides, free fatty acids and glucose, showed no significant results in the univariate regression analysis. However, dyslipidaemia and hyperglycaemia were found in obese or overweight patients [33], and the modulating potential of vitamin $\mathrm{D}$ in adipogenesis was previously examined [89].

In the present study, the general data analysis and literature review clearly established the associations between $s 25(\mathrm{OH}) \mathrm{D}_{3}$ 
A

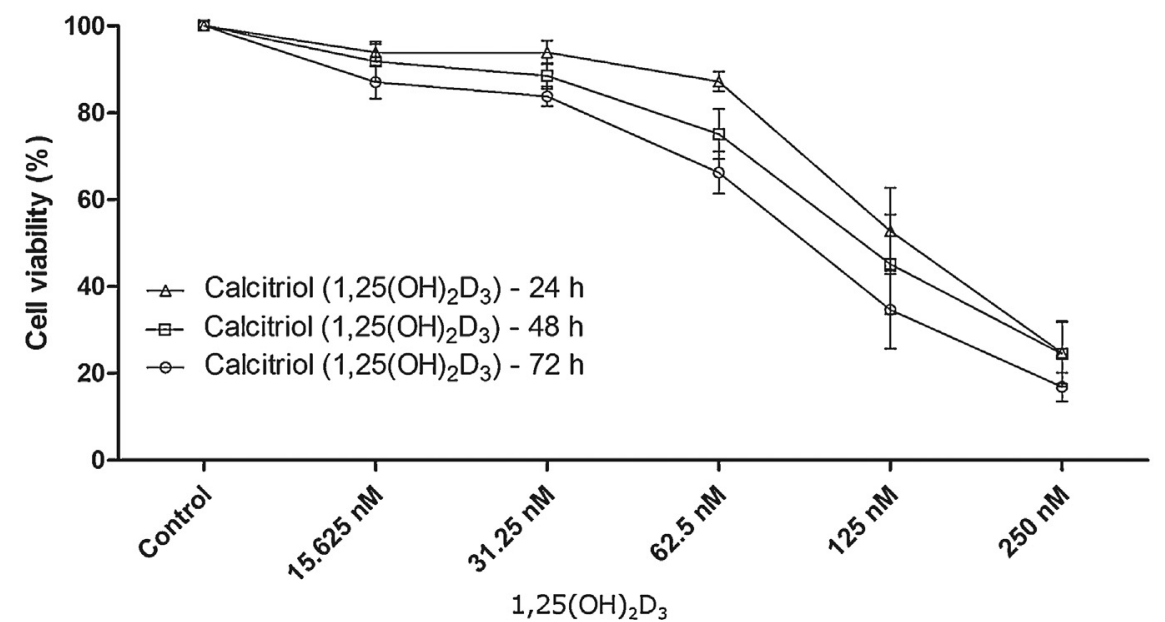

B

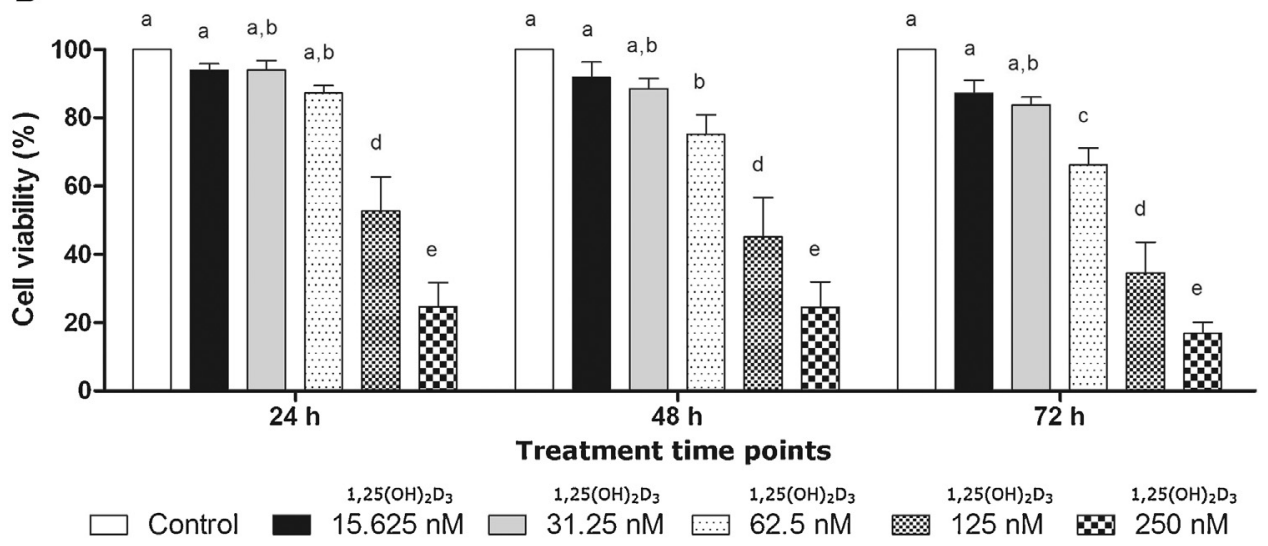

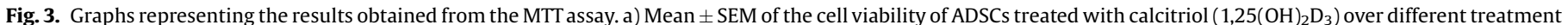

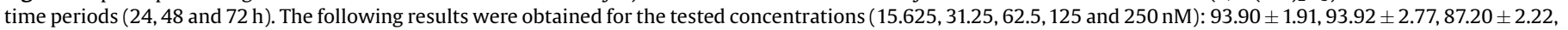

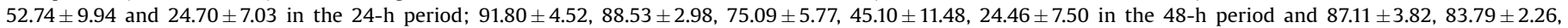

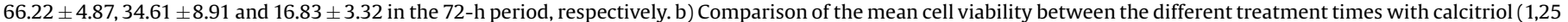

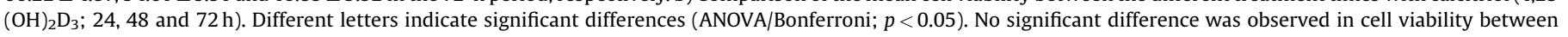

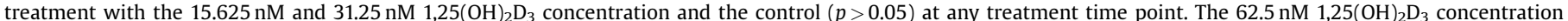

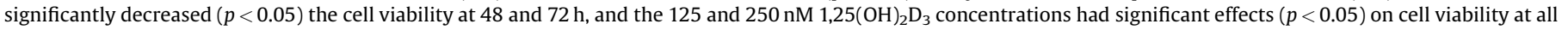
treatment time points.

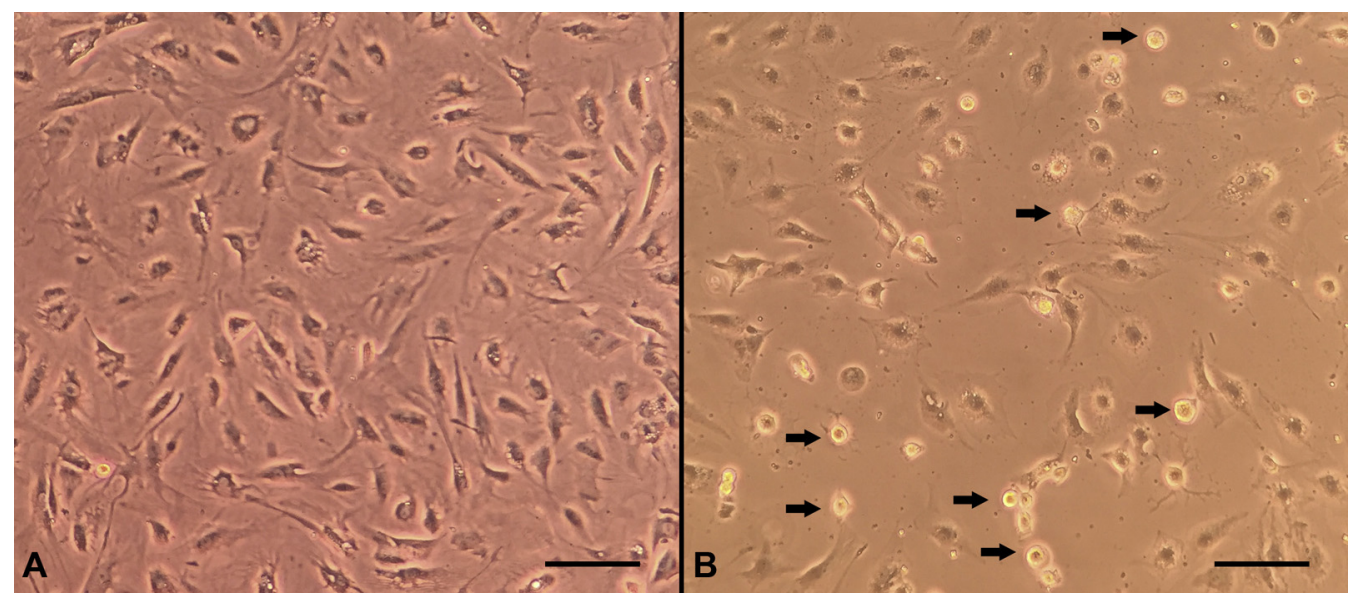

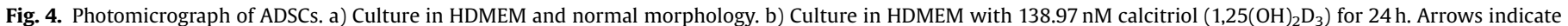
detached cells with the loss of the fibroblastoid appearance. Bars represent $50 \mu \mathrm{m}$. 
deficiency, various anthropometric and biochemical variables and metabolic disorders, including obesity-related diseases. No study variable was a significant predictor of the $s 25(\mathrm{OH}) \mathrm{D}_{3}$ concentration $\geq 30 \mathrm{ng} / \mathrm{mL}$. Conversely, BMI, age, HDL-c, glucose and sun exposure were significant predictors of the $\mathrm{s} 25(\mathrm{OH}) \mathrm{D}_{3}$ concentration $<30$ $\mathrm{ng} / \mathrm{mL}$.

Obesity affects approximately $13 \%$ of the global population [90]. In Brazil, obesity affects almost one in five Brazilians according to the Ministry of Health (Ministério da Saúde, Brasil) [63]. These data are worrying and place a burden on public health spending worldwide. Additionally, the Brazilian Unified Health System (Sistema Único de Saúde-SUS) spends approximately 150 million US dollars treating obesity-related diseases [91].

The body fat percentage and BMI are two key analysis parameters for obesity, and both parameters have been reported to be inversely correlated with obesity [92,93]. Our results also support this inference and increase interest in a better understanding of the cellular biology of obesity and its correlation with vitamin D levels. However, the relevance of vitamin D and the differentiation and/or cell death process to the biology of obesity is a key factor that requires further study [43]. The current understanding indicates that obesity results from a combination of three key events: (I) adipocyte hypertrophy; (II) hyperplasia of ADSCs and (III) the balance between the cell differentiation process (stem cells into adipocytes) and the cytostatic and/or cytotoxic effects on ADSCs, pre-adipocytes or adipocytes themselves [34]. Using an in vitro test system, our study showed that the viability of ADSCs depended on the time and concentration used for vitamin D supplementation (i.e., the viability of ADSCs was affected by the vitamin D concentration and exposure time). The IC50, which was between the two highest tested $1,25(\mathrm{OH})_{2} \mathrm{D}_{3}$ concentrations, was also calculated based on those results.

The MTT assay is commonly used to evaluate cell viability primarily through cytotoxic evaluation of the tested compound. Our results corroborate and complete the findings of Valle, Almalki and Agrawal [94]. These authors examined the cytotoxicity of 1,25 $(\mathrm{OH})_{2} \mathrm{D}_{3}$ by testing the release of the enzyme glucose-6-phosphate dehydrogenase in porcine ADSCs at a $100 \mathrm{nM}$ concentration to assess cytotoxicity and necrosis at that tested concentration. Thus, the experimental data reported herein may promote the study of new anti-obesity treatments considering $1,25(\mathrm{OH})_{2} \mathrm{D}_{3}$ supplementation and the biology of obesity, particularly the cytotoxic effects on cells that cause adipose tissue hyperplasia.

\section{Conclusions}

Given the above findings, the present study suggests that hypovitaminosis D is prevalent in the southern Brazilian study population and establishes a correlation between a low serum vitamin D concentration and increased LDL-c, low sun exposure (indoor work environment) and increased body fat. These findings suggest a key association between vitamin D deficiency and the development of obesity. Furthermore, the in vitro test performed in this study indicates that vitamin D supplementation may be a strategy for the development of anti-obesity treatments because this vitamin induces cell death (i.e., has a cytotoxic effect on ADSCs), which may be responsible for adipose tissue hyperplasia.

\section{Acknowledgements}

This work was supported by the Fundação de Apoio ao Desenvolvimento do Ensino, Ciência e Tecnologia de Mato Grosso do Sul under grant number 79/2014 (23/200.225/2014) and the Conselho Nacional de Desenvolvimento Científico e Tecnológico CNPq - under grant number 447205/2014-5. We thank Carlos
Roberto Audi Ayres, Edwin José Torres de Oliveira and Sidney Paulo Miyashiro for their support.

\section{References}

[1] H.A. Bischoff-Ferrari, W.C. Willett, J.B. Wong, A.E. Stuck, H.B. Staehelin, E.J. Orav, A. Thoma, D.P. Kiel, J. Henschkowski, Prevention of nonvertebral fractures with oral vitamin D and dose dependency: a meta-analysis of randomized controlled trials, Arch. Intern. Med. 169 (6) (2009) 551-561.

[2] S. Fan, X. Ni, J. Wang, Y. Zhang, S. Tao, W. Kong, Y. Li, J. Li, High prevalence of suboptimal Vitamin D status and bone loss in adult short bowel syndrome even after weaning off parenteral nutrition, Nutr. Clin. Pract. 32 (2) (2016) 258-265.

[3] L. Vuolo, C. Di Somma, A. Faggiano, A. Colao, Vitamin D and cancer, Front. Endocrinol. (Lausanne) 3 (2012) 58.

[4] M. Osanai, G.H. Lee, CYP24A1-induced vitamin D insufficiency promotes breast cancer growth, Oncol. Rep. 36 (5) (2016) 2755-2762.

[5] J. Gee, H. Bailey, K. Kim, J. Kolesar, T. Havighurst, K.D. Tutsch, W. See, M.B. Cohen, N. Street, L. Levan, D. Jarrard, G. Wilding, Phase II open label, multicenter clinical trial of modulation of intermediate endpoint biomarkers by 1alpha-hydroxyvitamin D2 in patients with clinically localized prostate cancer and high grade pin, Prostate 73 (9) (2013) 970-978.

[6] M.L. Melamed, E.D. Michos, W. Post, B. Astor, 25-hydroxyvitamin D levels and the risk of mortality in the general population, Arch. Intern. Med. 168 (15) (2008) 1629-1637.

[7] R. Jorde, Y. Figenschau, M. Hutchinson, N. Emaus, G. Grimnes, High serum 25hydroxyvitamin D concentrations are associated with a favorable serum lipid profile, Eur. J. Clin. Nutr. 64 (12) (2010) 1457-1464.

[8] S. Vogt, J. Baumert, A. Peters, B. Thorand, R. Scragg, Waist circumference modifies the association between serum 25( $\mathrm{OH}) \mathrm{D}$ and systolic blood pressure: results from NHANES 2001-2006, J. Hypertens. 34 (4) (2016) 637-645.

[9] S. Soskic, E. Stokic, E.R. Isenovic, The relationship between vitamin D and obesity, Curr. Med. Res. Opin. 30 (6) (2014) 1197-1199.

[10] D. Hollander, K.S. Muralidhara, A. Zimmerman, Vitamin D-3 intestinal absorption in vivo: influence of fatty acids, bile salts, and perfusate $\mathrm{pH}$ on absorption, Gut 19 (4) (1978) 267-272.

[11] J.L. Omdahl, E.A. Bobrovnikova, S. Choe, P.P. Dwivedi, B.K. May, Overview of regulatory cytochrome P450 enzymes of the vitamin D pathway, Steroids 66 (3-5) (2001) 381-389.

[12] M.O. Premaor, T.W. Furlanetto, Hipovitaminose D em adultos: entendendo melhor a apresentação de uma velha doença, Arquivos Brasileiros Endocrinologia Metabologia 50 (2006) 25-37.

[13] M.F. Holick, Vitamin D status: measurement, interpretation, and clinical application, Ann. Epidemiol. 19 (2) (2009) 73-78.

[14] M.F. Holick, Vitamin D deficiency, N. Engl. J. Med. 357 (3) (2007) 266-281.

[15] M.G. Kimlin, N.J. Downs, A.V. Parisi, Comparison of human facial UV exposure at high and low latitudes and the potential impact on dermal vitamin D production, Photochem. Photobiol. Sci. 2 (4) (2003) 370-375.

[16] M.F. Holick, T.C. Chen, Vitamin D deficiency: a worldwide problem with health consequences, Am. J. Clin. Nutr. 87 (4) (2008) 1080S-1086S.

[17] S.J. Felton, M.S. Cooke, R. Kift, J.L. Berry, A.R. Webb, P.M. Lam, F.R. de Gruijl, A. Vail, L.E. Rhodes, Concurrent beneficial (vitamin D production) and hazardous (cutaneous DNA damage) impact of repeated low-level summer sunlight exposures, Br. J. Dermatol. 175 (6) (2016) 1320-1328.

[18] K.D. Cashman, K.G. Dowling, Z. Skrabakova, M. Gonzalez-Gross, J. Valtuena, S. De Henauw, L. Moreno, C.T. Damsgaard, K.F. Michaelsen, C. Molgaard, R. Jorde, G. Grimnes, G. Moschonis, C. Mavrogianni, Y. Manios, M. Thamm, G.B. Mensink, M. Rabenberg, M.A. Busch, L. Cox, S. Meadows, G. Goldberg, A. Prentice, J.M. Dekker, G. Nijpels, S. Pilz, K.M. Swart, N.M. van Schoor, P. Lips, G. Eiriksdottir, V. Gudnason, M.F. Cotch, S. Koskinen, C. Lamberg-Allardt, R.A. Durazo-Arvizu, C.T. Sempos, M. Kiely, Vitamin D deficiency in Europe: pandemic? Am. J. Clin. Nutr. 103 (4) (2016) 1033-1044.

[19] C.M. Curtain, M. Williams, J.M. Cousins, G.M. Peterson, T. Winzenberg, Vitamin D supplementation in Tasmanian nursing home residents, Drugs Aging 33 (10) (2016) 747-754.

[20] S. Savastio, F. Cadario, G. Genoni, G. Bellomo, M. Bagnati, G. Secco, R. Picchi, E. Giglione, G. Bona, Vitamin D deficiency and glycemic status in children and adolescents with type 1 diabetes mellitus, PLoS One 11 (9) (2016) e0162554.

[21] A. Hossein-nezhad, M.F. Holick, Vitamin D for health: a global perspective, Mayo Clin. Proc. 88 (7) (2013) 720-755.

[22] F. Sadaf, Vitamin D deficiency -still a dilemma!, anaesthesia, Pain Intensive Care 20 (2) (2016) 2

[23] A. Bener, M. Al-Ali, G.F. Hoffmann, Vitamin D deficiency in healthy children in a sunny country: associated factors, Int. J. Food Sci. Nutr. 60 (Suppl. 5) (2009) 6070.

[24] M.D. Unger, L. Cuppari, S.M. Titan, M.C. Magalhaes, A.L. Sassaki, L.M. dos Reis, V. Jorgetti, R.M. Moyses, Vitamin D status in a sunny country: where has the sun gone? Clin. Nutr. 29 (6) (2010) 784-788.

[25] C.A. Nowson, J.J. McGrath, P.R. Ebeling, A. Haikerwal, R.M. Daly, K.M. Sanders, M.J. Seibel, R.S. Mason, A. Working Group of, B. New Zealand, E.S.o.A. Mineral Society, A., Osteoporosis, Vitamin D and health in adults in Australia and New Zealand: a position statement, Med J Aust 196(11)(2012)686-7.

[26] S.J. Muhairi, A.E. Mehairi, A.A. Khouri, M.M. Naqbi, F.A. Maskari, J. Al Kaabi, A.S Al Dhaheri, N. Nagelkerke, S.M. Shah, Vitamin D deficiency among healthy adolescents in Al ain, United Arab Emirates, BMC Public Health 13 (2013) 33. 
[27] B.S. Peters, L.C. dos Santos, M. Fisberg, R.J. Wood, L.A. Martini, Prevalence of vitamin D insufficiency in Brazilian adolescents, Ann. Nutr. Metab. 54 (1) (2009) 15-21.

[28] S.A. de Sousa Studart, A.C. Leite, A.L. Marinho, A.C. Pinto, C.N. Rabelo Junior, R. de Melo Nunes, H.A. Rocha, F.A. Rocha, Vitamin D levels in juvenile idiopathic arthritis from an equatorial region, Rheumatol. Int. 35 (10) (2015) 1717-1723.

[29] R.B. Moraes, G. Friedman, I.C. Wawrzeniak, L.S. Marques, F.M. Nagel, T.C. Lisboa, M.A. Czepielewski, Vitamin D deficiency is independently associated with mortality among critically ill patients, Clinics (Sao Paulo) 70 (5) (2015) 326 332.

[30] A.T. da Cunha, H.T. Pereira, S.L. de Aquino, C.H. Sales, K.C. Sena-Evangelista, J.G Lima, S.C. Lima, L.F. Pedrosa, Inadequacies in the habitual nutrient intakes of patients with metabolic syndrome: a cross-sectional study, Diabetol Metab Syndr 8 (2016) 32.

[31] P. Autier, M. Boniol, C. Pizot, P. Mullie, Vitamin D status and ill health: a systematic review, Lancet Diabetes Endocrinol 2 (1) (2014) 76-89.

[32] E. Theodoratou, I. Tzoulaki, L. Zgaga, J.P. Ioannidis, Vitamin D and multiple health outcomes: umbrella review of systematic reviews and meta-analyses of observational studies and randomised trials, BMJ 348 (2014) g2035.

[33] M.M. Elseweidy, R.S. Amin, H.H. Atteia, M.A. Ali, Vitamin D3 intake as regulator of insulin degrading enzyme and insulin receptor phosphorylation in diabetic rats, Biomed. Pharmacother. 85 (2017) 155-159.

[34] J. Jo, O. Gavrilova, S. Pack, W. Jou, S. Mullen, A.E. Sumner, S.W. Cushman, V. Periwal, Hypertrophy and/or hyperplasia: dynamics of adipose tissue growth, PLoS Comput. Biol. 5 (3) (2009) e1000324.

[35] J. Ye, J.M. Gimble, Regulation of stem cell differentiation in adipose tissue by chronic inflammation, Clin. Exp. Pharmacol. Physiol. 38 (12) (2011) 872-878.

[36] A. Eljaafari, M. Robert, M. Chehimi, S. Chanon, C. Durand, G. Vial, N. Bendridi, A. M. Madec, E. Disse, M. Laville, J. Rieusset, E. Lefai, H. Vidal, L. Pirola, Adipose tissue-Derived stem cells from obese subjects contribute to inflammation and reduced insulin response in adipocytes through differential regulation of the Th1/Th17 balance and monocyte activation, Diabetes 64 (7) (2015) 2477-2488.

[37] I.N. Sergeev, The role of Vitamin D in obesity and diabetes: ca2+ signaling, insulin secretion, adipocyte apoptosis, and bone mineralisation, FASEB J. 30 (1 Supplement) (2016) 128.1.

[38] F. Artaza, M.G. Sirad, 1,25(OH)2vitamin D3 inhibits cell proliferation by promoting cell cycle arrest without inducing apoptosis and modifies cell morphology of mesenchymal multipotent cells, J. Steroid Biochem. Mol. Biol 119 (1-2) (2010) 73-83.

[39] R. Ducloux, E. Nobecourt, J.M. Chevallier, H. Ducloux, N. Elian, J.J. Altman, Vitamin D deficiency before bariatric surgery: should supplement intake be routinely prescribed? Obes. Surg. 21 (5) (2011) 556-560.

[40] S. Christakos, M. Hewison, D.G. Gardner, C.L. Wagner, I.N. Sergeev, E. Rutten, A. G. Pittas, R. Boland, L. Ferrucci, D.D. Bikle, Vitamin D: beyond bone, Ann. N. Y. Acad. Sci. 1287 (2013) 45-58.

[41] C.K. Chakraborti, Vitamin D as a promising anticancer agent, Indian J. Pharmacol. 43 (2) (2011) 113-120.

[42] S. Brakta, J.S. Diamond, A. Al-Hendy, M.P. Diamond, S.K. Halder, Role of vitamin D in uterine fibroid biology, Fertil. Steril. 104 (3) (2015) 698-706.

[43] I.N. Sergeev, 1 25-Dihydroxyvitamin D3 induces Ca2+-mediated apoptosis in adipocytes via activation of calpain and caspase-12, Biochem. Biophys. Res. Commun. 384 (1) (2009) 18-21.

[44] J.I. Botella-Carretero, F. Alvarez-Blasco, J.J. Villafruela, J.A. Balsa, C. Vazquez, H. F. Escobar-Morreale, Vitamin D deficiency is associated with the metabolic syndrome in morbid obesity, Clin. Nutr. 26 (5) (2007) 573-580.

[45] E.E. Delvin, M. Lambert, E. Levy, J. O'Loughlin, S. Mark, K. Gray-Donald, G. Paradis, Vitamin D status is modestly associated with glycemia and indicators of lipid metabolism in French-Canadian children and adolescents, J. Nutr. 140 (5) (2010) 987-991.

[46] U. Ekelund, H. Sepp, S. Brage, W. Becker, R. Jakes, M. Hennings, N.J. Wareham, Criterion-related validity of the last 7-day, short form of the International Physical Activity Questionnaire in Swedish adults, Public Health Nutr. 9 (2) (2006) 258-265.

[47] W.T. Friedewald, R.I. Levy, D.S. Fredrickson, Estimation of the concentration of low-density lipoprotein cholesterol in plasma, without use of the preparative ultracentrifuge, Clin. Chem. 18 (6) (1972) 499-502.

[48] C.F. Markarian, G.Z. Frey, M.D. Silveira, E.M. Chem, A.R. Milani, P.B. Ely, A.P. Horn, N.B. Nardi, M. Camassola, Isolation of adipose-derived stem cells: a comparison among different methods, Biotechnol. Lett. 36 (4) (2014) 693-702.

[49] L.C. Hermeto, R. DeRossi, R.J. Oliveira, J.R. Pesarini, A.C. Antoniolli-Silva, P.H. Jardim, A.E. Santana, E. Deffune, J.C. Rinaldi, L.A. Justulin, Effects of intraarticular injection of mesenchymal stem cells associated with platelet-rich plasma in a rabbit model of osteoarthritis, Genet. Mol. Res. 15 (3) (2016).

[50] L.C. Hermeto, R. Rossi, P.H. Jardim, A.E. Santana, J.C. Rinaldi, L.A. Justulin, Comparison between two different experimental models of osteoarthritis in rabbits. Intra-articular collagenase injection and anterior cruciate ligament transection, Acta Cir. Bras. 31 (9) (2016) 602-607.

[51] P.A. Zuk, M. Zhu, H. Mizuno, J. Huang, J.W. Futrell, A.J. Katz, P. Benhaim, H.P. Lorenz, M.H. Hedrick, Multilineage cells from human adipose tissue: implications for cell-based therapies, Tissue Eng. 7 (2) (2001) 211-228.

[52] A. Urt-Filho, R.J. Oliveira, L.C. Hermeto, J.R. Pesarini, N. David, B. Cantero Wde, G. Falcao, G. Marks, A.C. Antoniolli-Silva, Mesenchymal stem cell therapy promotes the improvement and recovery of renal function in a preclinical model, Genet. Mol. Biol. 39 (2) (2016) 290-299.
[53] M. Camassola, L.M. de Macedo Braga, P.C. Chagastelles, N.B. Nardi, Methodology, biology and clinical applications of human mesenchymal stem cells, Methods Mol. Biol. 879 (2012) 491-504.

[54] T. Mosmann, Rapid colorimetric assay for cellular growth and survival: application to proliferation and cytotoxicity assays, J. Immunol. Methods 65 (1-2) (1983) 55-63.

[55] M.O. Mauro, D. Sartori, R.J. Oliveira, P.L. Ishii, M.S. Mantovani, L.R. Ribeiro, Activity of selenium on cell proliferation, cytotoxicity, and apoptosis and on the expression of CASP9, BCL-XL and APC in intestinal adenocarcinoma cells, Mutat. Res. 715 (1-2) (2011) 7-12.

[56] T. Karonova, O. Belyaeva, E.B. Jude, A. Tsiberkin, A. Andreeva, E. Grineva, P. Pludowski, Serum 25(OH)D and adipokines levels in people with abdominal obesity, J. Steroid Biochem. Mol. Biol. (2016), doi:http://dx.doi.org/10.1016/j. jsbmb.2016.09.005 (in press) S0960-0760(16)30241-2.

[57] S.S. Maeda, I.S. Kunii, L. Hayashi, M. Lazaretti-Castro, The effect of sun exposure on 25-hydroxyvitamin D concentrations in young healthy subjects living in the city of São Paulo, Brazil, Braz. J. Med. Biol. Res. 40 (2007) 1653-1659.

[58] F. Cobayashi, B.H. Lourenco, M.A. Cardoso, 25-Hydroxyvitamin D3 levels, Bsml polymorphism and insulin resistance in brazilian amazonian children, Int. J. Mol. Sci. 16 (6) (2015) 12531-12546.

[59] V.M. Lopes, J.R. Lopes, J.P. Brasileiro, I. Oliveira, R.P. Lacerda, M.R. Andrade, N.I. Tierno, R.C. Souza, L.A. Motta, Highly prevalence of vitamin D deficiency among Brazilian women of reproductive age, Arch. Endocrinol. Metab. 61 (1) (2017) 21-27.

[60] Ministério da Saúde-Governo Federal (2011). (Ministry of Health (Brazil), Federal Government; 2011). Fact sheet. Pesquisa de Orçamento Familiar (POF2008/2009) - Antropometria e estado nutricional de crianças, adolescentes e adultos no Brasil. <http://www.abeso.org.br/uploads/downloads/70/ 553a23f27da68.pdf $>$ (Accessed 17 April 2017).

[61] J. MacLaughlin, M.F. Holick, Aging decreases the capacity of human skin to produce vitamin D3, J. Clin. Invest. 76 (4) (1985) 1536-1538.

[62] L. Flicker, K. Mead, R.J. MacInnis, C. Nowson, S. Scherer, M.S. Stein, J. Thomasx, J. L. Hopper, J.D. Wark, Serum vitamin D and falls in older women in residential care in Australia, J. Am. Geriatr. Soc. 51 (11) (2003) 1533-1538.

[63] Ministério da Saúde - Governo Federal (2017). (Ministry of Health (Brazil) Federal Government; 2017). Fact sheet. Sistema de vigilância de fatores de risco e proteção para doenças crônicas por inquérito telefônico <http:// portalarquivos.saude.gov.br/images/pdf/2017/abril/17/Vigitel_17-4-17-final. pdf $>$ (Accessed 17 April 2017).

[64] M.J. Bolland, A.B. Grey, R.W. Ames, B.H. Mason, A.M. Horne, G.D. Gamble, I.R. Reid, Determinants of vitamin D status in older men living in a subtropical climate, Osteoporos. Int. 17 (12) (2006) 1742-1748.

[65] M.F. Holick, Vitamin D: a d-lightful solution for health, J. Investig. Med. 59 (6) (2011) 872-880

[66] S. Kannan, H.W. Lim, Photoprotection and vitamin D: a review, Photodermatol. Photoimmunol. Photomed. 30 (2-3) (2014) 137-145.

[67] J. Wortsman, L.Y. Matsuoka, T.C. Chen, Z. Lu, M.F. Holick, Decreased bioavailability of vitamin D in obesity, Am. J. Clin. Nutr. 72 (3) (2000) 690-693.

[68] F. Alshahrani, N. Aljohani, Vitamin D: deficiency, sufficiency and toxicity, Nutrients 5 (9) (2013) 3605-3616.

[69] N.M. Aljefree, P. Lee, J.M. Alsaqqaf, F. Ahmed, Association between Vitamin D status and coronary heart disease among adults in Saudi Arabia: a case-control study, Healthcare (Basel) 4 (4) (2016).

[70] K.J. Rawat, N.H. Sabnis, U. Saraf, G. Surana, Myopathy effect of Vitamin D deficiency beyond bones, J. Assoc. Physicians India 64 (10) (2016) 86-87.

[71] S. Salekzamani, H. Mehralizadeh, A. Ghezel, Y. Salekzamani, M.A. Jafarabadi, A. S. Bavil, B.P. Gargari, Effect of high-dose vitamin D supplementation on cardiometabolic risk factors in subjects with metabolic syndrome: a randomized controlled double-blind clinical trial, J. Endocrinol. Invest. 39 (11) (2016) 1303-1313.

[72] X. Yin, Q. Sun, X. Zhang, Y. Lu, C. Sun, Y. Cui, S. Wang, Serum 25(OH)D is inversely associated with metabolic syndrome risk profile among urban middle-aged Chinese population, Nutr. J. 11 (2012) 68

[73] A. Tedgui, Z. Mallat, Atherosclerotic plaque formation, Rev. Prat. 49 (19) (1999) 2081-2086.

[74] M.C. Phillips, Molecular mechanisms of cellular cholesterol efflux, J. Biol Chem. 289 (35) (2014) 24020-24029.

[75] K. Yin, D.K. Agrawal, Vitamin D and inflammatory diseases, J. Inflamm. Res. 7 (2014) 69-87.

[76] J. Oh, S. Weng, S.K. Felton, S. Bhandare, A. Riek, B. Butler, B.M. Proctor, M. Petty, Z. Chen, K.B. Schechtman, L. Bernal-Mizrachi, C. Bernal-Mizrachi, 1,25(OH)2 vitamin d inhibits foam cell formation and suppresses macrophage cholesterol uptake in patients with type 2 diabetes mellitus, Circulation 120 (8) (2009) 687-698.

[77] P. Costet, Y. Luo, N. Wang, A.R. Tall, Sterol-dependent transactivation of the ABC1 promoter by the liver X receptor/retinoid X receptor, J. Biol. Chem. 275 (36) (2000) 28240-28245.

[78] F. Matsuura, N. Wang, W. Chen, X.C. Jiang, A.R. Tall, HDL from CETP-deficient subjects shows enhanced ability to promote cholesterol efflux from macrophages in an apoE- and ABCG1-dependent pathway, J. Clin. Invest. 116 (5) (2006) 1435-1442.

[79] K.A. Rye, C.A. Bursill, G. Lambert, F. Tabet, P.J. Barter, The metabolism and antiatherogenic properties of HDL, J. Lipid Res. (2009) S195-S200.

[80] R.F. Chun, A.L. Lauridsen, L. Suon, L.A. Zella, J.W. Pike, R.L. Modlin, A.R Martineau, R.J. Wilkinson, J. Adams, M. Hewison, Vitamin D-binding protein 
directs monocyte responses to 25-hydroxy- and 1,25-dihydroxyvitamin $\mathrm{D}, \mathrm{J}$. Clin. Endocrinol. Metab. 95 (7) (2010) 3368-3376.

[81] K. Yin, Y. You, V. Swier, L. Tang, M.M. Radwan, A.N. Pandya, D.K. Agrawal, Vitamin D protects against atherosclerosis via regulation of cholesterol efflux and macrophage polarisation in hypercholesterolemic swine, Arterioscler. Thromb. Vasc. Biol. 35 (11) (2015) 2432-2442.

[82] P.S. Jellinger, D.A. Smith, A.E. Mehta, O. Ganda, Y. Handelsman, H.W. Rodbard, M.D. Shepherd, J.A. Seibel, A.T.F.f.M.o. Dyslipidemia, A. Prevention of, American Association of Clinical Endocrinologists' Guidelines for Management of Dyslipidemia and Prevention of Atherosclerosis: executive summary, Endocr. Pract. 18(2) (2012) 269-93.

[83] T. Skaaby, L.L. Husemoen, T. Martinussen, J.P. Thyssen, M. Melgaard, B.H. Thuesen, C. Pisinger, T. Jorgensen, J.D. Johansen, T. Menne, B. Carlsen, P.B. Szecsi, S. Stender, R.V. Fenger, M. Fenger, A. Linneberg, Vitamin D status, filaggrin genotype, and cardiovascular risk factors: a Mendelian randomization approach, PLoS One 8 (2) (2013) e57647.

[84] L.H. Li, X.Y. Yin, C.Y. Yao, X.C. Zhu, X.H. Wu, Serum 25-hydroxyvitamin D, parathyroid hormone, and their association with metabolic syndrome in Chinese, Endocrine 44 (2) (2013) 465-472.

[85] Z. Asemi, T. Hashemi, M. Karamali, M. Samimi, A. Esmaillzadeh, Effects of vitamin D supplementation on glucose metabolism, lipid concentrations, inflammation, and oxidative stress in gestational diabetes: a double-blind randomized controlled clinical trial, Am. J. Clin. Nutr. 98 (6) (2013) 1425-1432.

[86] A.M. Heikkinen, M.T. Tuppurainen, L. Niskanen, M. Komulainen, I. Penttila, S. Saarikoski, Long-term vitamin D3 supplementation may have adverse effects on serum lipids during postmenopausal hormone replacement therapy, Eur. J. Endocrinol. 137 (5) (1997) 495-502.
[87] J.C. Zhou, Y.M. Zhu, P. Guo, Z. Chen, F.Z. Xie, X.L. Liu, S. He, Serum 25(OH)D and lipid levels in Chinese obese and normal weight males before and after oral vitamin D supplementation, Biomed. Environ. Sci. 26 (10) (2013) 801-807.

[88] H. Wang, N. Xia, Y. Yang, D.Q. Peng, Influence of vitamin D supplementation on plasma lipid profiles: a meta-analysis of randomized controlled trials, Lipids Health Dis. 11 (2012) 42.

[89] R.J. Wood, Vitamin D and adipogenesis: new molecular insights, Nutr. Rev. 66 (1) (2008) 40-46.

[90] W. H. Organization, Obesity and Overweight. Fact Sheet 311 Jun 2016, (2016).

[91] Ministério da Saúde-Governo Federal (2013). (Ministry of Health (Brazil), Federal Government; 2013). Fact sheet. Prevenção e tratamento: Doenças ligadas à obesidade custam $\mathrm{R} \$ 488$ milhões. < http://portalsaude.saude.gov. $\mathrm{br} /$ index.php/cidadao/principal/agencia-saude/noticias-anteriores-agenciasaude/3414-> (Accessed 17 April 2017).

[92] S. Oliai Araghi, S.C. van Dijk, A.C. Ham, E.M. Brouwer-Brolsma, A.W. Enneman, E. Sohl, K.M.A. Swart, N.L. van der Zwaluw, J.P. van Wijngaarden, R.A.M. Dhonukshe-Rutten, N.M. van Schoor, M.C. Zillikens, P. Lips, L. de Groot, A.G. Uitterlinden, N. van der Velde, BMI and body fat mass is inversely associated with vitamin D levels in older individuals, J. Nutr. Health Aging (2015) 1-6.

[93] A. Bellia, C. Garcovich, M. D'Adamo, M. Lombardo, M. Tesauro, G. Donadel, P. Gentileschi, D. Lauro, M. Federici, R. Lauro, P. Sbraccia, Serum 25hydroxyvitamin D levels are inversely associated with systemic inflammation in severe obese subjects, Intern. Emerg. Med. 8 (1) (2013) 33-40.

[94] Y.L. Valle, S.G. Almalki, D.K. Agrawal, Vitamin D machinery and metabolism in porcine adipose-derived mesenchymal stem cells, Stem Cell Res. Ther. 7 (1) (2016) 118 